\title{
Pengaruh Konsentrasi Glutaraldehida Terhadap Aktivitas Transesterase Enzim Lipase Terimobilisasi pada Proses Pembuatan Biodiesel dari Minyak Goreng Bekas
}

\author{
The Effect of Glutaraldehyde Concentration for Transesterase Activities of Immobilized Lipase \\ on Biodiesel Production Process from Used Cooking Oil
}

\author{
Susan Primadevi* dan Dian Kresnadipayana \\ Fakultas Ilmu Kesehatan, Universitas Setia Budi \\ *Corresponding author: sanchemic.nnes@gmail.com
}

\begin{abstract}
ABSTRAK
Penggunaan lipase sebagai biokatalis mempunyai beberapa kelemahan yaitu lipase tidak dapat digunakan kembali karena terlarut dalam media reaksi, struktur lipase sangat tidak stabil terhadap adanya perubahan lingkungan (suhu, $p H$, kekuatan ionik), sehingga menyebabkan enzim terdenaturasi. Solusi untuk mengatasi kelemahan penggunaan enzim tersebut adalah dengan imobilisasi enzim pada chitosan beads dengan metode crosslinking. Tujuan penelitian ini adalah mengetahui pengaruh variasi konsentrasi glutaraldehida terhadap aktivitas transesterase enzim lipase terimobilisasi pada proses pembuatan biodiesel .

Penelitian diawali dengan pembuatan kitosan dari limbah cangkang rajungan. Kitosan serbuk kemudian dimodifikasi bentuknya melalui proses swelling menjadi chitosan beads. Tahap kedua adalah pemurnian minyak goreng bekas melalui tahap despicing, netralisasi dan bleaching. Tahap ketiga yaitu imobilisasi enzim lipase pada chitosan beads dengan metode crosslinking dengan menggunakan variasi konsentrasi glutaraldehida. Tahap terakhir adalah pembuatan biodiesel dari minyak goreng bekas. Hasil penelitian menunjukkan bahwa kitosan yang dihasilkan memiliki rendemen sebesar 39,43\%, derajat deasetilasi 83,83\%, kadar abu 0,73\%, kadar air 4,74\% dan kadar nitrogen 7,18\%. Chi-

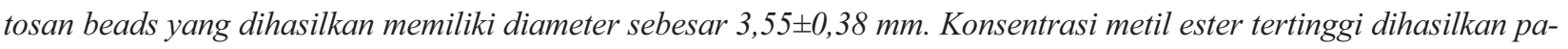
da saat konsentrasi glutaraldehida $2 \%$.
\end{abstract}

Kata kunci: chitosan beads, imobilisasi lipase, glutaraldehida, biodiesel

\section{ABSTRACT}

The usage of lipases as a biocatalyst have several weakness, namely lipases can not be reused because it dissolved in the medium of reaction, it is unstable to a environmental changes (temperature, pH, ionic strength), causing the denaturation of enzymes. The solution to overcome disadvantages of lipases usage is immobilization of enzymes on chitosan beads with crosslinking method. The purpose of this study was to determine the effect of glutaraldehyde concentration to transesterase activity of immobilized lipase on the process of biodiesel making.

This first step of this research was making the chitosan from crab shell waste, then chitosan powder modified through swelling process into chitosan beads. The second step was the purification of used cooking oil through despicing, neutralization and bleaching. The third step was the immobilization of lipase on chitosan beads via crosslinking method using variations of glutaraldehyde concentration. The last step was the making of biodiesel from used cooking oil. The results showed that chitosan produced yield of $39,43 \%$, deacetylation degree of $83,83 \%$, ash content of $0,73 \%$, water content of $4,74 \%$ and nitrogen content of 7,18\%. Chitosan beads had a diameter of 3,55 $\pm 0,38 \mathrm{~mm}$. The highest methyl ester was produced on concentration glutaraldehyde of $2 \%$.

Keywords: chitosan beads, immobilization of lipases, glutaraldehyde, biodiesel

\section{PENDAHULUAN}

Enzim adalah biokatalisator yang banyak digunakan pada berbagai bidang industri seperti makanan, kimia, dan medis. Aktivitas enzim lipase yang menarik untuk dipelajari adalah aktivitas transesterase. Keuntungan penggunaan en- zim lipase pada reaksi transesterifikasi adalah kondisi operasi dapat dilakukan pada keadaan lunak (mild) dan proses pemisahan gliserol dapat dilakukan dengan mudah tanpa perlu dilakukan proses pemurnian atau menghasilkan limbah kimia. Hal tersebut menyebabkan reaksi enzima- 
tis berpotensi untuk diaplikasikan pada pembuatan biodiesel karena bisa menghasilkan biodiesel dengan kualitas baik, rendemen yang tinggi, energi dan biaya produksi yang rendah.

Penggunaan lipase sebagai biokatalis ternyata juga mempunyai beberapa kelemahan diantaranya lipase tidak dapat digunakan kembali karena terlarut dalam media reaksi. Menurut Krajewska (2004) struktur lipase sangat tidak stabil terhadap adanya perubahan lingkungan (suhu, $\mathrm{pH}$, kekuatan ionik, dan gangguan lainnya), sehingga menyebabkan enzim terdenaturasi (Chibata, 1978). Tingginya harga enzim juga menjadikan proses enzimatis menjadi tidak ekonomis.

Salah satu cara mengatasi kelemahan dalam penggunaan enzim tersebut adalah dengan imobilisasi enzim. Salah satu metode yang banyak digunakan adalah metode pengikatan silang (crosslinking) enzim pada matriks pendukung dengan glutaraldehida sebagai crosslinking agent. Keuntungan metode ini adalah ikatan antara enzim dan matriks pendukungstabil sehingga enzim tidak mudah lepas ke dalam larutan dan substrat dapat dengan mudah berinteraksi karena enzim berada pada permukaan matriks pendukung (Brena et al., 2006).

Matriks pendukung yang digunakan pada proses imobilisasi harus mempunyai bentuk dan ukuran pori yang cocok, area permukaan yang luas, tidak larut dalam air, memiliki stabiltas termal dan kimia yang tinggi serta dapat diregenerasi. Kitosan menarik digunakan sebagai matriks pendukung karena mempunyai beberapa sifat yang menguntungkan antara lain hidrofilisitas, biokompatibilitas, biodegradabilitas, anti bakteri dan mempunyai afinitas yang besar terhadap enzim.

Kitosan serbuk dapat dimodifikasi menjadi chitosan bead melalui proses swelling. Chitosan bead dapat meningkatkan efektivitas penggunaan ulang kitosan sebagai matriks pendukung selama proses imobilisasi.

Faktor-faktor yang harus diperhatikan selama proses imobilisasi dengan metode pengikatan silang yaitu waktu imobilisasi, $\mathrm{pH}$, konsentrasi matriks pendukung, konsentrasi glutaraldehida dan konsentrasi enzim. Penelitian ini bertujuan untuk mempelajari pengaruh konsentrasi glutaraldehida terhadap aktivitas transesterase enzim lipase terimobilisasi pada proses pembuatan biodiesel dari minyak goreng bekas.

\section{BAHAN DAN METODE Bahan}

Bahan-bahan yang digunakan dalam penelitian ini adalah cangkang rajungan (diperoleh dari CV. Sekawan Mina), enzim lipase (Merck), minyak goreng bekas (diperoleh dari penjual gorengan di wilayah Surakarta), abu sekam padi, kertas saring Whatman41, kertas saring, kertas indikator $\mathrm{pH}$, akuades, bahan dari Merck berkualitas p.a, yaitu: glutaraldehida, natrium hidroksida $(\mathrm{NaOH})$, asam klorida $(\mathrm{HCl})$, metanol $\left(\mathrm{CH}_{3} \mathrm{OH}\right)$, etanol $\left(\mathrm{C}_{2} \mathrm{H}_{5} \mathrm{OH}\right)$, asam asetat $\left(\mathrm{CH}_{3} \mathrm{COOH}\right)$, nheksana, $\mathrm{BF}_{3}$ dalam metanol, natrium hidrogen fosfat $\left(\mathrm{Na}_{2} \mathrm{HPO}_{4} 2 \mathrm{H}_{2} \mathrm{O}\right)$, natrium dihidrogen fosfat $\left(\mathrm{NaH}_{2} \mathrm{PO}_{4} 2 \mathrm{H}_{2} \mathrm{O}\right)$, tembaga (II) sulfat $\left(\mathrm{CuSO}_{4}\right.$ $\left.5 \mathrm{H}_{2} \mathrm{O}\right)$, kalium natrium tatrat $\left(\mathrm{KNaC}_{4} \mathrm{H}_{4} \mathrm{O}_{6} 4 \mathrm{H}_{2} \mathrm{O}\right)$, BSA (Bovin Serum Albumin), kaporit teknis.

\section{Metode Penelitian}

\section{A. Pembuatan Kitosan dan Chitosan Beads}

a. Pembuatan kitosan

Cangkang rajungan dicuci dan direndam dalam larutan kaporit teknis $4 \%$ selama 15 menit, kemudian cangkang kepiting dikeringkan pada suhu kamar. Cangkang rajunganyang sudah kering, ditumbuk sampai setengah kasar, diblender sampai halus dan diayak dengan ayakan 250 mesh agar ukuran butirannya homogen.

Deproteinasi dilakukan dengan cara mencampurkan $50 \mathrm{~g}$ serbuk cangkang kepiting dengan $500 \mathrm{~mL}$ larutan $\mathrm{NaOH} 4 \%$ (b/v) dan campuran dipanaskan selama 2 jam pada suhu $65^{\circ} \mathrm{C}$. Residu dicuci dengan akuades sampai netral dan dikeringkan dalam oven pada suhu $65^{\circ} \mathrm{C}$ selama 2 jam.

Demineralisasi dilakukan dengan cara men- 
campurkan residu dengan larutan $\mathrm{HCl} 1 \mathrm{M}$ dengan perbandingan $1: 15$ dan diaduk selama 3 jam pada suhu kamar. Residu dicuci dengan akuades sampai netral. Kitin yang diperoleh dikeringkan dalam oven pada suhu $65^{\circ} \mathrm{C}$ selama 2 jam.

Deasetilasi dilakukan dengan cara mencampurkan kitin yang diperoleh dengan larutan $\mathrm{NaOH} 50 \%$ (b/v) dengan perbandingan 1:10, dan campuran dipanaskan selama 1 jam pada suhu $100{ }^{\circ} \mathrm{C}$. Residu dicuci dengan akuades hingga netral. Kitosan yang diperoleh kemudian dikeringkan dalam oven selama 2 jam pada suhu $65^{\circ} \mathrm{C}$ dan dianalisis dengan spektrofotometer FTIR.

\section{b. Pembuatan chitosan beads}

Satu gram kitosan serbuk dilarutkan ke dalam larutan asam asetat $1 \%(\mathrm{v} / \mathrm{v})$, kemudian dimasukkan melalui jarum syringe (26G) ke dalam $100 \mathrm{~mL}$ zat koagulan (larutan $\mathrm{NaOH} 1 \mathrm{M}$ dalam 26\% (v/v) etanol). Campuran dibiarkan selama 3 jam, sampai terbentuk gel berbentuk bulat. Chitosan beads yang terbentuk disaring dan dicuci sampai netral.

\section{B. Pemurnian Minyak Goreng Bekas (Siswani et al., 2012):}

\section{a. Proses despicing}

Minyak goreng bekas ditambah dengan akuades dengan perbandingan 1:1 dan dipanaskan sampai volume akuades menjadi setengahnya. Campuran disaring dengan kertas saring untuk memisahkan kotoran-kotoran yang mengendap.

\section{b. Proses netralisasi}

Minyak goreng bekas hasildespicingdipanaskan sampai suhu $35^{\circ} \mathrm{C}$, kemudian tambahkan larutan $\mathrm{NaOH}$ 16\% dengan komposisi $4 \mathrm{ml}$ setiap $100 \mathrm{ml}$ minyak. Campuran diaduk selama $10 \mathrm{me}-$ nit pada suhu $40^{\circ} \mathrm{C}$.Campuran didinginkan, kemudian disaring untuk memisahkan minyak goreng dengan kotoran.

\section{c. Proses bleaching}

Minyak goreng bekas hasil netralisasi dipanas- kan sampai suhu $70^{\circ} \mathrm{C}$, kemudian abusekam padi dimasukkan ke dalam larutan minyak goreng (dengan perbandingan 6,25 gram abu sekam padiper 100 gram minyak goreng). Larutan diaduk menggunakan magnetic stirrer selama 60 menit dan suhu ditingkatkan sampai $100^{\circ}$ C.Campuran disaring untuk memisahkan minyak goreng dari kotoran.

\section{Imobilisasi Enzim Lipase}

Satu gram chitosan beads dimasukkan ke dalam botol Falcon $50 \mathrm{~mL}$ dan direndam dalam larutan glutaraldehida berbagai konsentrasi $(0,125 \%$, 0,25\%, 0,50\% dan 1\%,2\%) selama 10 menit. Chitosan beads kemudian disaring dan dicuci lalu direndam dalam larutan enzim lipase 1\% (30 mg dalam $3 \mathrm{~mL}$ bufer fosfat $\mathrm{pH}$ 6) selama 60 menit.

\section{Pembuatan Biodiesel}

Minyak goreng bekas ditambah dengan metanol dengan perbandingan 1:6 dan dimasukkan ke dalam botol falcon $50 \mathrm{~mL}$. Ke dalam campuran ditambahkan $1 \mathrm{~g}$ chitosan beads terimobilisasi dan direaksikan selama 5 jam pada temperatur $37{ }^{\circ} \mathrm{C}$ dalam shaker incubator. Filtrat dianalisis kandungan senyawa metil ester asam lemak (FAME) dengan menggunakan GC.

\section{HASIL DAN PEMBAHASAN}

\section{A. Pembuatan Kitosan}

Proses pembuatan kitosan dilakukan dengan metode No dan Meyer (1989) yang terdiri dari tiga tahap yaitu: (1) deproteinasi, (2) demineralisasi, dan (3) deasetilasi. Isolasi kitin diawali dengan tahap deproteinasi kemudian dilanjutkan dengan tahap demineralisasi, karena menurut Johnson dan Peniston (1982) deproteinasi yang dilakukan pada tahap awal dapat memaksimumkan hasil dan mutu protein serta mencegah kontaminasi protein pada proses demineralisasi.

Tahap deproteinasi diawali dengan merefluks serbuk cangkang rajungan menggunakan larutan $\mathrm{NaOH} 4 \%$ (1:10). Pada tahap ini, protein akan terlepas dari serbuk cangkang rajungan dan mem- 
bentuk Na-proteinat yang dapat larut dan hilang selama proses pencucian dan penyaringan (Ruswati, et al., 2007). Hal ini ditunjukkan dengan perubahan warna larutan dari jernih menjadi coklat. Reaksi yang terjadi sebagai berikut:

Protein $+\mathrm{NaOH} \longrightarrow \quad \mathrm{Na}$ proteinat $+\mathrm{H}_{2} \mathrm{O}$

Residu hasil deproteinasi ditambahkan larutan $\mathrm{HCl} 1 \mathrm{M}$ dengan perbandingan 1:15 (w/v). Tujuan tahap demineralisasi, yaitu menghilangkan mineral-mineral yang terkandung dalam cangkang rajungan ( $P$. pelagicus), yaitu kalsium karbonat $\left[\mathrm{CaCO}_{3}\right]$ dan kalsium fosfat $\left[\mathrm{Ca}_{3}\left(\mathrm{PO}_{4}\right)_{2}\right]$ menggunakan larutan $\mathrm{HCl}$. Pada tahap ini, ketika larutan $\mathrm{HCl} 1 \mathrm{M}$ direaksikan dengan serbuk cangkang rajungan akan terbentuk buih yang yang terkumpul pada permukaan larutan. Setelah kurang lebih 30 menit buih akan berkurang dan larutan berwarna kuning keruh. Terbentuknya buih tersebut menandakan adanya gas karbon dioksida $\left(\mathrm{CO}_{2}\right)$ dan uap air. Hasil demineralisasi berbentuk serbuk berwarna coklat tua. Residu yang dihasilkan pada tahap ini disebut kitin.

Reaksi yang terjadi selama proses demineralisasi sebagai berikut :

$\mathrm{CaCO}_{3(\mathrm{~s})}+2 \mathrm{HCl}_{(\mathrm{aq})} \longrightarrow \mathrm{CaCl}_{2(\mathrm{aq})}+\mathrm{H}_{2} \mathrm{O}_{(\mathrm{l})}+\mathrm{CO}_{2(\mathrm{~g})}$

$\mathrm{Ca}_{3}\left(\mathrm{PO}_{4}\right)_{2(\mathrm{~s})}+4 \mathrm{HCl}_{(\mathrm{aq})} \longrightarrow 2 \mathrm{CaCl}_{2(\mathrm{aq})}+\mathrm{Ca}\left(\mathrm{H}_{2} \mathrm{PO}_{4}\right)_{2(\mathrm{aq})}$

Tahap terakhir adalah penghilangan gugus asetil pada kitin yang disebut tahap deasetilasi. Proses deasetilasi diawali dengan merefluks kitin dengan larutan $\mathrm{NaOH} 40 \%$ dengan perbandingan (1:10). Pada tahap ini digunakan larutan $\mathrm{NaOH}$ konsentrasi yang cukup tinggi karena bisa mengoptimalisasi transformasi gugus asetil yang berikatan dengan atom nitrogen membentuk gugus amina. Perendaman dengan larutan $\mathrm{NaOH}$ konsentrasi tinggi akan meningkatkan derajat deastilasi dan mengakibatkan depolimerisasi yaitu memutuskan ikatan rangkap antara gugus karboksil dengan atom nitrogen (Rochima, et al., 2007). Hasil karakterisasi kitosan yang dihasilkan disajikan pada Tabel 1.

\section{B. Pembuatan Chitosan Beads}

Chitosan bead dibuat dengan proses swelling yaitu pelarutan kitosan serbuk dalam larutan asam asetat kemudian diteteskan ke dalam larutan $\mathrm{NaOH}$. Chitosan bead yang dihasilkan berbentuk bola gel yang berwarna putih dengan diameter

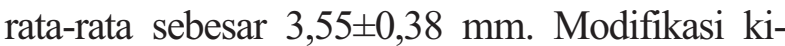
tosan serbuk menjadi chitosan bead bertujuan untuk meningkatkan efektivitas penggunaan ulang kitosan sebagai matriks pendukung dalam proses imobilisasi, karena setelah akhir reaksi enzim lipase terimobilisasi pada chitosan bead lebih mudah dipisahkan dari produk daripada enzim lipase terimobilisasi pada kitosan serbuk. Proses swelling hanya mengubah bentuk fisik dari kitosan sehingga diharapkan chitosan bead mempunyai gugus fungsi yang hampir sama dengan kitosan. Gugus fungsi chitosan bead yang hampir sama dengan kitosan memungkinkan terbentuknya interaksi yang sama pula antara kitosan serbuk-enzim serta chitosan bead-enzim.

\section{Imobilisasi Enzim Lipase}

Imobilisasi enzim dengan pengikatan silang memiliki beberapakeuntungan yaitu ikatan kovalen yang terbentuk tidak mudah putus akibat ada-

Tabel 1. Karakterisasi Kitosan

\begin{tabular}{|l|l|l|}
\hline No. & $\begin{array}{l}\text { Karakter } \\
\text { Kitosan }\end{array}$ & Persentase \\
\hline 1 & Rendemen & $39,43 \%$ \\
\hline 2 & $\begin{array}{l}\text { Derajat } \\
\text { deasetilasi }\end{array}$ & $83,83 \%$ \\
\hline 3 & Kadar abu & $0,73 \%$ \\
\hline 4 & Kadar air & $4,74 \%$ \\
\hline 5 & Kadar nitrogen & $7,18 \%$ \\
\hline
\end{tabular}


nya pengaruh $\mathrm{pH}$, kekuatan ion atau substrat, dan stabilitas enzim imobil yang tinggi. Efektivitas imobilisasi bergantung pada padatan pendukung yang digunakan dan teknik imobilisasi yang dipilih. Teknik imobilisasi yang digunakan dalam penelitian ini adalah dengan metode pengikatan silang (crosslinking) pada suatu padatan pendukung. Padatan pendukung yang digunakan pada penelitian ini adalah chitosan bead yang diikat silang dengan jembatan bifungsional glutaraldehida.

Enzim dan kitosan susahberikatan secara langsung pada proses imobilisasi, oleh karenaitu diperlukan glutaraldehida sebagai jembatan penghubung (Miao dan Swee, 2000). Glutaraldehida merupakan jembatan bifungsional yang memiliki dua gugus karbonil (-CHO). Pada proses imobilisasi gugus amina $\left(-\mathrm{NH}_{2}\right)$ chitosan bead akan berikatan dengan salah satu gugus -CHO glutaraldehida, demikian juga gugus amina $\left(-\mathrm{NH}_{2}\right)$ enzim akan berikatan dengan gugus - $\mathrm{CHO}$ glutaraldehida pada ujung lainnya. Interaksi yang terjadi antara gugus karbonil (-CHO) glutaraldehida dengan gugus amina $\left(-\mathrm{NH}_{2}\right)$ baik pada enzim dan chitosan bead yaitu melalui reaksi basa Schiff. Chitosan bead yang sudah diimobilisasi dengan enzim lipase melalui pengikatan silang menggunakan glutaraldehida warnanya menjadi kuning dan teksturnya lebih keras atau kaku.

\section{Pemurnian Minyak Goreng Bekas}

Substrat yang digunakan sebagai bahan baku pembuatan biodiesel adalah minyak goreng bekas. Mutu minyak dapat ditentukan dari beberapa faktor seperti kandungan air, asam lemak, kotoran dalam minyak, warna, dan bilangan penyabunan (Ketaren, 1986). Selama proses penggorengan, minyak goreng akan mengalami perubahan sifat fisika dan kimia. Minyak setelah penggorengan mengalami beberapa perubahan fisika yaitu penurunan titik cair, kenaikan indeks bias, warna minyak menjadi lebih gelap, peningkatan viskositas dan berat jenis serta terbentuknya busa selama proses penggorengan. Perubahan sifat ki- mia minyak yang terjadi selama penggorengan meliputi kenaikan kandungan asam lemak bebas, penurunan bilangan iod dan kenaikan bilangan peroksida yang berhubungan dengan kerusakan flavor.

Minyak goreng bekas sebelum diolah menjadi biodiesel terlebih dahulu dimurnikan melalui proses despicing, netralisasi dan bleaching. Proses despicing bertujuan untuk menghilangkan bumbu-bumbu yang terlarut dalam minyak setelah proses penggorengan, sedangkan netralisasi bertujuan untuk mengurangi asam lemak bebas dalam minyak goreng bekas. Penetralan adalah suatu reaksi antara asam dengan basa, sehingga menghasilkan suatu senyawa yang netral. Dalam proses penetralan sebagai asamnya adalah asam lemak sedangkan sebagai basanya adalah natrium hidroksida $(\mathrm{NaOH})$. Bleaching (pemucatan) bertujuan untuk menguapkan air, asam lemak dengan berat molekul rendah, aldehid dan keton hasil degradasi minyak. Minyak goreng bekas yang awalnya berwarna coklat setelah dimurnikan berubah menjadi kuning jernih.

\section{E. Pembuatan Biodiesel}

Aktivitas enzim lipase terimobilisasi diuji dengan menggunakan reaksi transesterifikasi minyak kelapa sawit dengan metanol. Hasil reaksi dianalisis dengan menggunakan kromatografi gas (GC). Keberhasilan enzim terimobilisasi dalam mengkatalisis reaksi transesterifikasi ditandai dengan terbentuknya FAME (Fatty Acid Methyl Ester). Kromatogram hasil uji GC tunjukkan pada Gambar 1.

Pada kromatogram muncul puncak-puncak yang merupakan metil ester yang dihasilkan dari reaksi transesterifikasi. Metil ester yang muncul pada waktu retensi sekitar 16 menit digunakan sebagai acuan untuk mengamati aktivitas enzim lipase karena memiliki resolusi yang baik dan bentuk puncak yang simetris. Analisis kuantitatif dilakukan dengan menghitung luas area yang dihasilkan.

Pengaruh konsentrasi glutaraldehida yang di- 


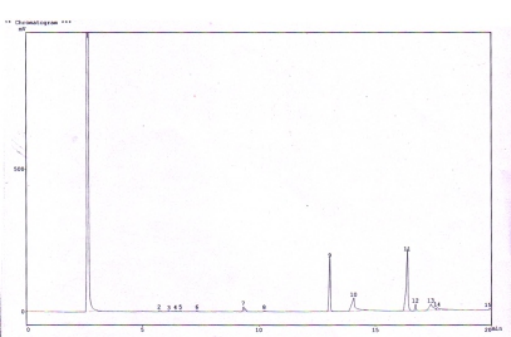

(a)

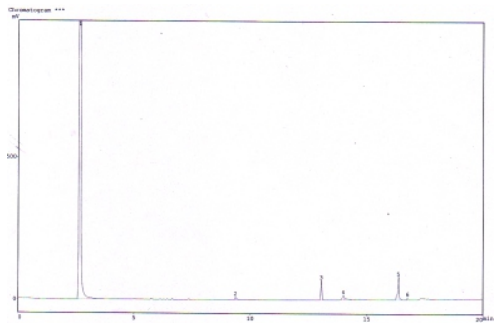

(d)

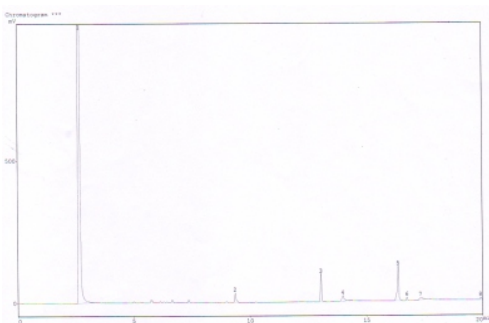

(b)

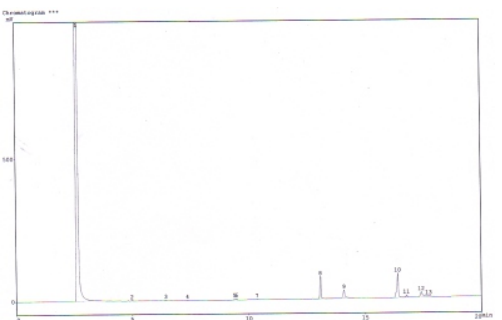

(c) Gambar 1. Konsentrasi glutaraldehid : (a) $2 \%$, (b) $1 \%$, (c) $0,5 \%$, (d) 0,25\%, (e) 0,125\%

\begin{tabular}{|l|l|l|l|}
\multicolumn{4}{|c}{ Tabel 2. Luas Area Metil Ester } \\
\hline No & $\begin{array}{l}\text { Konsentrasi } \\
\text { Glutaraldehid }\end{array}$ & $\begin{array}{l}\text { Puncak } \\
\text { ke- }\end{array}$ & Luas Area \\
\hline 1 & $2 \%$ & 11 & 1.167 .649 \\
\hline 2 & $1 \%$ & 5 & 555.212 \\
\hline 3 & $0,5 \%$ & 10 & 377.696 \\
\hline 4 & $0,25 \%$ & 5 & 355.903 \\
\hline 5 & $0,125 \%$ & 5 & 350.343 \\
\hline
\end{tabular}

gunakan pada proses imobilisasi dapat diketahui dari luas area metil ester yang dihasilkan seperti yang ditunjukkan pada Tabel 2 .

Tabel 2 memperlihatkan bahwa semakin tinggi konsentrasi glutaraldehida yang digunakan pada proses imobilisasi, maka semakin tinggi pula konsentrasi metil ester yang dihasilkan. Jumlah metil ester yang dihasilkan dari minyak goreng bekas tidak sebanyak metil ester yang dihasilkan dari minyak goreng baru karena pada minyak goreng bekas banyak mengandung asam lemak bebas dan air yang bisa menghambat proses pembentukan produk pada reaksi transesterifikasi.

\section{KESIMPULAN}

1. Kitosan yang dihasilkan memiliki rendemen sebesar 39,43\% dengan derajat deasetilasi sebesar $83,83 \%$ dengan kadar abu $0,73 \%$, kadar air 4,74\% dan kadar nitrogen 7,18\%.

2. Chitosan beads yang dihasilkan memiliki diameter sebesar 3,55 $\pm 0,38 \mathrm{~mm}$.

3. Semakin tinggi konsentrasi glutaraldehida yang digunakan pada proses imobilisasi, semakin tinggi pula konsentrasi metil ester yang dihasilkan.

\section{DAFTAR PUSTAKA}

Brena, B. M., dan Batista-Viera F., 2006, Immobilization of Enzymes, di dalam Immobilizationof Enzymes and Cells, Humana Press, Spanyol.

Chibata, I., 1978, Immobilized Enzymes, Research and Development, Kodansha LTD, Tokyo.

Johnson, E. L, and Peniston, Q. P, 1982, Utilization of Shellfish Waste for Production of Chitin and Chitosan Production, in Chemistry and Biochemistry of Marine Food Product, AVI Publ., Westport Connecticut.

Ketaren, S., 1986, Pengantar Teknologi Minyak danLemak Pangan, UI-Press, Jakarta.

Krajewska, B., 2004, Application of Chitin and Chitosan-Based Materials for Enzyme Immobilizations : a Review, Enz. Microb. Technol., 35, 126-139.

Miao, Y., and Swee, N. T., 2000, Amperometric Hydrogen Peroxide Biosensor Based on Immobilization of Peroxidase in Chitosan Matrix Crosslinked with Glutaraldehide, Analyst, 125, 1591-1594.

No, H. K., And Meyer, S.P., 1989, Preparation of Chitin and Chitosan, di dalam Chitin Handbook, Muzzarelli, R. A. A., and Peter, M. G., European Chitin Soc., Grottamare.

Rochima, et al., 2007, Viskositas dan Berat Molekul Kitosan Hasil Reaksi Enzimatis Kitin Deasetilasi Isolat, Makalah $\mathrm{Na}$ sional, IPB, Bogor.

Ruswanti, et al., 2007, Membran Kitosan Padat dari Cangkang Rajungan (Portunus pelagicus) dan Aplikasinya Sebagai Adsorben Ion Mangan(II) dan Besi(II), Jurnal, Universitas Diponegoro, Semarang.

Siswani, E. D., Kristianingrum, S., dan Suwardi, 2012, Sintesis dan Karakterisasi Biodiesel dari Minyak Jelantah pada Berbagai Waktu Dan Suhu, Prosiding Seminar Nasional Penelitian, Pendidikan dan Penerapan MIPA, Fakultas MIPA, Universitas Negeri Yogyakarta, 2 Juni 2006, K-103-K-112.6 